\title{
Review of ethico-legal aspects of tissue retention in the medico-legal practice in Sri Lanka
}

\author{
UCP Perera \\ Lecturer in Forensic Medicine, Faculty of Medicine, University of Ruhuna, Galle.
}

\begin{abstract}
Modern medical research depends heavily on the donation and use of human tissue and organs. Though tissue samples provide a valuable resource for research, such research can only be carried out if it satisfies particular regulations in a country and has approval from appropriate ethics committee/s [1]. Tissue retention policies in both clinical and pathological settings in Sri Lanka are still in the wilderness and academics and clinicians are at crossroads with regard to adoption and application of ethical standards in research involving tissue retention.
\end{abstract}

Large scale autopsy tissue retention has not been witnessed in Sri Lanka until the last few years though tissue and organ retention in clinical practice has continued routinely with 'informed consent' obtained from patients in a very lax manner. In a situation where public awareness about tissue retention policies are at subthreshold levels, the clinicians and researchers are enjoying a wide spectrum of freedom related to retention of tissues. This has lead to professional malpractices some instances. The situation in Sri Lanka is far from satisfactory. We have gained worldwide for eye donation in the last decades of the twentieth century through the generosity of the common public. It is not clear whether effective legislative amendments are going to be implemented in the near future to restructure the tissue retention policies. New legislation would be only part of the overall process in creating awareness among the public and professionals when participating and conducting research using human tissue [2]. Secondary legislation including formal ethical guidelines laid down by academic and professional bodies will be needed to support legislation. However such guidelines are still in its infancy in Sri Lanka.

\section{Current legislative framework with regard to tissue retention}

The Sri Lankan death investigation system is a modified version of the British Coroner system. The death investigator equivalent to a British Coroner is called as the 'Investigator into deaths' and is appointed by the Minister of Justice for a specified area of jurisdiction under the Judicature Act 1978 [3]. Though they bear quasi magisterial powers in the official capacity almost all of them are non-medical, non-legal appointees heavily dependent on the police and forensic pathologists (Judicial Medical Officers ) for death investigation matters. The autopsy practice in Sri Lanka is guided by the provisions laid down in S.369 - S.373 of the Code of Criminal Procedure Act No. 15 of 1979 [4]. Sri Lanka does not have a separate Coroner's Act unlike the United Kingdom and Australia and Coroners / IDs duties are also guided by the Code of Criminal Procedure Act. There is no legislation in place to govern non-coroner (hospital) post-mortem examinations in Sri Lanka. These are currently administered by hospital regulations drafted by the Ministry of Health. It is noteworthy that donation of human bodies to Medical Faculties for anatomical purposes in Sri Lanka are not regulated by any legislation such as the Anatomy Acts that exist in the United Kingdom and Australia.

The first legislative enactment on tissue retention in post independent Sri Lanka was the Corneal Grafting Act 1955, which regulated post-mortem eye donation for therapeutic purposes [5]. The Human Tissue Transplantation Act No. 50 of 1987 was introduced in the latter part of the twentieth century to regularize some aspects of tissue retention mainly in the direction of transplantation [6]. In fact the first Kidney transplantation was done in Sri Lanka in 1988 and many transplants have been done subsequently. 
The Act provides definitions for key terms such as 'Death', 'Tissue', and 'Donor' and is a general legal framework for donation of tissues in Sri Lanka. It is in no way equivalent to Anatomy or Human tissue Acts and is significantly deficient with regard to the tissue retention issues at present. The Act is already 19 years old and needs extensive revision in the light of current developments in surgical and pathology practices in Sri Lanka. It is apparent that the tissue retention policies and practices in Sri Lanka are not effectively guided by appropriate legislation and hence provide ample space for unlawful and unethical retention of tissues, research practices and non-adherence to the principles of informed consent. Thus, the vulnerability of the Sri Lankan population has increase and extra space is provided for exploitation by abusing their good will for tissue donation. This was mainly evident in the post tsunami research attempts in Sri Lanka designed according to the interests of international collaborators.

\section{Current ethical standards}

Currently all Medical aculties and major hospitals in Sri Lanka have their own Ethical Review Committees (ERC) comprised of internal experts from various disciplines. Recently there was an attempt to formulate standards for a National Ethics Committee by consensus of all ethics committees of Medical Ffaculties. At present all research proposals concerning clinical and pathological practice should be submitted for approval of appropriate ERC's prior to conducting research activities. However, given the fact that most of the ERC members are not trained or experienced in ethico-legal standards of research or tissue retention and there is no uniformity in ERC activities it is not difficult to obtain approval for a research proposal in Sri Lanka. The Sri Lanka Medical Council has laid down general ethical guidelines for its members which cannot be equated to specific ethical standards required to be maintained in research activities. Though National Professional Associations such as the Sri Lanka Medical Association (SLMA), Sri Lanka Association for Advancement of Science (SLAAS) and the National Science Foundation
(NSF) have their own ethics committees, tissue retention has never been an issue set against international ethical norms in developed Sri Lanka.

\section{Socio-cultural perception on tissue retention}

Sri Lanka is a multi religious country where the four major religions - Buddhism, Hinduism, Christianity and Islam is practiced. Both Buddhism and Hinduism have no objections to tissue donation where as Christians and Muslims don't strictly accept it on the basis of religious teachings. The majority of the Sri Lankan population are Buddhists who posses a rich tradition of donation of tissues and organs heavily promoted by the Buddhist principles. Donation of tissue and organs is an inherent principle in Buddhist doctrine as described "Jathaka stories" where the Buddha himself donated all his organs in previous births during his long and difficult path to attain enlightenment. Donation is a principle that all lay and clergy should promote within themselves according to the basic Buddhist teachings.

To understand the practice of organ and tissue donation in contemporary Sri Lanka, an appreciation of dâna is crucial. Within Theravada Buddhism there are three ways in which dâna may be practiced. The first of these is referred to as dâna pâramita, the act of donating one's worldly goods, food, labour, and in one famous instance - the wife and children. The second is a more dedicated act of giving known as dâna upa pâramita, which involves the donation of body parts (anga) to those in need. Finally, dâna paramattha pâramita is the ultimate gift, in which one's life is sacrificed for the sake of others. In each of these acts of giving the object is not merely to benefit others but to demonstrate a healthy lack of attachment to the very things that fuel illusion of selfhood. The illustrations of how the Buddha in previous existences practised all three of these types of giving are found in a variety of places in the body of stories which relate episodes from his incarnations as a Boddhisattva, otherwise known as the Jâtakas [7].

Traditional Buddhists in all Asian countries almost never reject requests for tissue acquisition or donation in clinical and pathological practice and it has been taken for granted by many unorthodox 
researchers to exploit public without informed consent to ascertain their research goals.

\section{Importance of post-mortem examination and tissue retention}

It is indisputable that post mortem examinations are critically important in informing relatives, clinicians and legal authorities about the cause of death and to bereaved families about the possibility of acquired and genetic diseases where care and treatment may be required. Appropriate examination of organs and tissue at post-mortem examination is essential in:

- improving clinical care and maintaining clinical standards;

- increasing our understanding of disease and

- in supporting clinical research and training.

\section{Coronal post mortem examinations}

It has been accepted normal practice to retain body parts removed during the post mortem examination for further pathological study, quality control or scientific purposes. This is lawful under the provisions of the Human Tissue Act in the United Kingdom (2004) [8]. Some Australian States and under the Code of Criminal Procedure Act in Sri Lanka (1979). Post mortem examinations requested by a Coroner/Inquirer into Deaths do not require consent and take precedence over any prior wishes of the deceased or their relatives. However, it is good practice to inform the families of the deceased about any requirement for a post mortem examination by the Coroner, and the implications in terms of their rights and expectations, working closely with the Coroner's office.
Therefore, the consent of next of kin should be obtained in relation to:

- retention of body parts for purposes other than the post mortem examination;

- disposal of those body parts, i.e.

○ reunited with the body of the deceased;

○ disposal by the organisation;

- retained for medical, scientific or therapeutic purposes and the period of retention, if limited;

- separate burial or cremation.

It is imperative that Sri Lanka develops its own ethico-legal standards as a matters of urgency in relation to tissue retention to prevent any serious medical improprieties.

\section{References}

1. Kapp MB. Ethical and legal issues in research involving human subjects: do you want a piece of me? Journal of Clinical Pathology 2006; 59: 335-9.

2. Mason JK. and Laurie GT. 2005 Law and Medical Ethics. $7^{\text {th }}$ edition, Oxford University Press. pp 51229.

3. Simpson B. Impossible Gifts: Bodies, Buddhism and Bioethics in Contemporary Sri Lanka. The Journal of the Royal Anthropological Institute, 2004; 10(4): 83959.

4. Corneal Grafting Act No. 38 of 1955 Sri Lanka.

5. Code of Criminal Procedure Act No. 15 of 1979, S. 369-73.

6. Human Tissue Transplantation Act No. 48 of 1987 Sri Lanka.

7. Human Tissue Act 2004, United Kingdom.

8. Ethical issues in organ and tissue transplantation to humans. Royal College of Pathologists, United Kingdom. Retrieved on 22.04.2006 from http://www.rcpath.org/resources/pdf/EthicalOrgan Transplant Human.pdf 